\title{
シンポジウム 1
}

\section{「バルーン内視鏡による診断・治療の進歩」}

司会

自治医科大学 内科学講座消化器内科学部門

山本 博徳

東京医科歯科大学医学部附属病院 光学医療診療部

大塚 和朗 
S1-01 機器レンタルでバルーン内視鏡を導入している 一般病院に打ける診断・治療の現況

横浜南共済病院 消化器内科

○飯塚千乃，金子 卓，岡 裕之，岡崎 博

【目的】当院は一般市中病院であり, シングルバルーン内視 鏡を機器レンタルの形で導入している。これまでに当院で 経験した症例を検討し，その現況と問題点について考察す る.【方法】2015年2月から2018年2月までに当院で施行した シングルバルーン内視鏡検查を対象とした，検査目的を A. 術後再建腸管に対するERCPとB.小腸疾患に対する精查加 療の $2 つ に$ 分け，目的別に解析を行った、【結果】A.術後再 建腸管に対するERCPは16例であり, 疾患は総胆管結石が 14例，悪性胆管狭窄が2例であった。目的部位到達率は $81.2 \%(13 / 16)$ であった。目的部位到達可能であった13例全 例で，目的手技を完遂できた。偶発症は認めなかった。 B. 小腸疾患は21例であった。扱入経路は経口のみが6例，経肛 門のみが11例, 経口・経肛門両方が4例であった。全小腸を 観察できた症例はなかった。疾患は小腸出血疑いが最も多 く, 11例中4例(36.4\%)で出血源を特定できた。 小腸腫瘍疑 いは6例であり，3例に腫瘍性病変を認めた。他，小腸狭窄 が3例，炎症性腸疾患疑いが1例であった。【考察】術後再建 腸管に対するERCPの治療成績は既報とほぼ同等であった が, 小腸疾患については目的達成率と全小腸観察率が低か った。

S1-03 表在性非乳頭部十二指腸腫瘍及び空腸腫瘍に 対する内視鏡的粘膜下層剥離術はバルーン 内視鏡を用いれば実現可能な治療手技となる 自治医科大学内科学講座 消化器内科部門 ○岩下ちひろ, 三浦義正, 井野裕治, 角田真人, 山本博徳 【背景】表在性非乳頭部十二指腸腫瘍 (SNADET) p空腸 腫瘍に対する内視鏡的粘膜下層剥離術(ESD)では、通常内 視鏡だと病変に届かなかったり操作性が悪いことを経験す る。当科ではこのような症例に打いてもバルーン内視鏡を 用いて積極的にESDを施行してきた。【目的】バルーン内視 鏡を用いたSNADET及び空腸腫瘍に対するESD症例の治療 成績の検討【方法】2006年10月から2017年9月の間に当科で 施行したSNADET及び空腸腫湯に対するバルーン内視鏡を 用いたESDの治療成績を後方視的に検討した。【結果】平均 年齢58歳。男性/女性 $5 / 4$ 、全十二指腸・小腸ESD58例の うち9例でバルーン内視鏡を使用した。スコープはEN450BI5またはEI-580BT（富士フイルム）を用い、全例で ST hood (DH-15GR)を装着した。先端バルーン併用は1例たミ った。8例でPCMでESDを施行した。部位は上十二指腸角/ 下十二指腸角/水平脚/空腸で1/3/5/1例、切除長径平均 $34.0 \mathrm{~mm}$ 、病変長径平均 $24.4 \mathrm{~mm}$ 、切除時間平均 119.8 分、 $\mathrm{R} 0$ 切除 $88.9 \%(8 / 9)$ 、腺腫/癌 5/4例だった。術中穿孔や遅発穿 孔は認めなかった。【結語】 PCMで安全性を担保し、バル ーン内視鏡で操作性を確保することで、SNADET及び空腸 腫瘍のESDが実現可能である。
S1-02 原因不明の消化管出血で発症した小腸潰瘍症に 対する、バルーン内視鏡による病因検索の意義 東京大学医学部 消化器内科

青木智則, 山田篤生, 小池和彦

【目的】原因不明の消化管出血(OGIB)の出血源となる小腸 潰瘍症の病因は多岐に渡る。腫瘍，クローン病，吻合部潰 瘍，感染性小腸炎，メッケル熄室，血管炎は，バルーン内 視鏡( $\mathrm{BE})$ で確定診断ができ, 手術や薬剤等の治療が検討で きる。一方, NSAIDs潰瘍, 虚血性小腸炎, 単純性潰瘍等 は，BEが確定診断に必須でなく有用性は限られる。尔腸潰 瘍症に対する病因診断目的のBEの適応を検討した。

【方法】4施設でOGIB精查のBEで診断した小腸潰瘍症43例 を対象とした，患者背景(overt/occult，黑色便/血便，内服 薬)と潰掦の内視鏡所見(単発/多発, 空腸/回腸)を調査し,

BEで確定診断出来た病因疾患に関連する因子を抽出した

【結果】 overt bleeding発症は72\%, NSAIDs内服は33\%で, 19例(44\%)が単発潰瘍，23例(56\%)が多発潰瘍であった，潰 瘍の主な病因は，NSAIDs潰瘍(30\%)，吻合部潰瘍(7\%)，虚 血性小腸炎(7\%), 小腸癌(9\%)で，35\%が不明であった．12例 (28\%)の疾患がBEで確定診断でき，その割合は単発潰瘍例 が多発潰貆例より高かった(単発 $58 \%$ vs. 多発 4\%, P< 0.001).

【結論】OGIB発症の小腸潰瘍症では, 単発潰瘍が病因診断 目的のBEの積極的な適応で, 多発潰湯はBEが病因診断に 寄与しにくい.

S1-04 大腸ESDにおけるバルーンオーバーチューブの 有用性

昭和大学藤が丘病院 消化器内科

○遠藤利行, 黒木優一郎, 上原なつみ, 阿曾沼邦央, 長浜正亞

【緒言】大腸 $\mathrm{ESD}$ の困難要因として操作性不良があり、対策 として2015年3月より大腸用バルーンオーバーチューブ

(ST-CB1: Olympus) を導入している。導入前後に执ける有 用性を検討した。【対象と方法】当院に扔ける大腸ESDのう ち術前内視鏡にて下行結腸以深で操作性不良と判断した 75 件中、ST-CB1を使用しなかった27件を conventional群(C群)、 使用した48件をtube群(T群)とし、両群を後ろ向きに比較検 討した。【結果】局在 $(\mathrm{C}, \mathrm{A}, \mathrm{T}, \mathrm{D})$ はC群 $(3,11,13,0) 、 \mathrm{~T}$ 群 $(5,14,25,4)$ であった。平均腫瘍径はC群 $29 \mathrm{~mm}(10-80)$ 、 T群 28.6mm(10-80)で、担癌率、腫瘍の浸潤度、繊維化含め 両者に差は認めなかった。一括切除率はC群 96.3\%(26/27)、 T群 97.9\%(47/48)で差は認めなかったが、一括完全切除率 ではC群 77.8\%(21/27)、T群 95.8\%(46/48)(p=0.0139)と有意 差を認めた。剥離速度（mm2/min）はC群18.4(4.5-43)と T 群19.78(5.5-45)では有意差は認めないがT群で速い傾向があ り、(C,A) と(T,D)の部位別では、より深部(C,A)で速い傾 向があった。穿孔率は両群で差は認めなかった。結語】操 作性不良の大腸ESDには、ST-CB1使用で切除時間短縮と一 括完全切除の向上に有用であった。 


\section{S1-05 シングルバルーン内視鏡を用いた術後再建腸管 症例の胆道処置}

亀田総合病院 消化器内科

白鳥俊康, 中路 聡, 平田信人

【諸言】従来、術後再建腸管に対する胆道処置は困難例とし て扱われていた。しかし、近年登場したショートタイプの バルーン内視鏡（以下SBE）を使用することで、内視鏡を 入れ替えずに、高い処置成功率を期待出来るようになった。 当院でもSBEを採用しており、その成績を報告する。【方法】 2017年〜2018年までにSBEで胆道処置を行った術後再建腸 管症例24例が対象。年齢中央值は73歳、男女比は $17: 7$ 。再 建腸管術式はB-2：PD：RY：残胃RYで3:6:7:8。原疾 患は、悪性狭窄：良性：胆管結石で6：3：15。【結果】全例 で乳頭部到達・処置完遂が可能であった。平均到達時間 25.3分、平均処置回数1.2回・平均処置時間44.5分であった。 偶発症を4例(16.7\%)で認めた。内訳はEST後出血2例・後腹 膜穿孔1例 ·急性膵炎1例で、いずれも内科的加療で対応可 能であった。【考察】SBEは乳頭部までの挿入性が良く、処 置完遂率も高いという結果であった。しかし、SBEのみで は胆道処置困難な症例も存在する。その際の対処法として、 前方斜視鏡に入れ替えることで処置が容易となる症例も経 験したため、合わせて報告する。

\section{S1-06 ダブルバルーン内視鏡を用いた良性胆管空腸 吻合部狭窄に対する金属ステント短期留置の 有用性}

東京大学大学院医学系研究科 消化器内科

○佐藤達也, 木暮宏史, 山田篤生, 中井陽介, 小池和彦 【目的】バルーン内視鏡の登場により術後の良性胆管空腸吻 合部狭窄に対する内視鏡的治療が可能となったが、時に難 治例に遭遇する。治療成績の向上を目指してダブルバルー ン内視鏡を用いた新規金属ステント短期留置による治療を 導入し、有効性、安全性を検証した。【方法】良性胆管空腸 吻合部狭窄症例に対し、Short-typeダブルバルーン内視鏡 を用いて金属ステント(BONASTENT M-Intraductal)を留 置した。留置期間は3ケ月とし、ステント抜去時に狭窄改善 の有無を評価した。【結果】2017年6月から2018年1月までに 11例にステント留置を行った。男性6名、女性5名、年齢 72(47-77)歳、初回治療7例。術式は膵頭十二指腸切除(PD) + Billroth II再建 + Braun吻合5例、PD+Roux-en-Y(R-Y)再建3 例、胆管空腸吻合 + R-Y再建3例。ステントは径8、10mm、 長さ4、5cmを使用した。9例でステントを抜去し、狭窄改 善率88.9\%、留置期間98(70-150)日であった。経過観察33(16157)日で狭窄再発なし。1例でステント近位端の肝内胆管に 過形成性変化を生じた。【考察】ダブルバルーン内視鏡を用 いた胆管空腸吻合部狭窄に対する金属ステント治療は短期 成績良好で安全な治療法である。

S1-08 当院でのクローン病に対するバルーン内視鏡 東京医科歯科大学 光学医療診療部11 東京医科歯科大学 消化器内科2

○竹中健人 ${ }^{11}$, 大塚和朗 ${ }^{1}$, 鈴木康平 ${ }^{11}$, 福田将義 ${ }^{11}$, 渡辺 守2)

【目的】当施設ではクローン病(CD)病変の精査のため、積極 的にシングルバルーン内視鏡(SBE)を施行している。今回、 CDに対するSBEの有効性について検討した。【方法】 2012 年5月から2017年12月までにMR

enterocolonography(MREC)とSBEを施行されたCD患者534 例(343名)を対象とした。内視鏡評価にはSES-CDを応用し、 SBEの病変検出率を評価した。また小腸病変とCDAIや CRPとの相関や、MRECとの比較について検討した。結果】 臨床的寛解の患者は74\%であり、CRP陰性は60\%であった。 SBEは一人法にて経肛門的に挿入し、挿入距離の中央値は 回盲弁より $140 \mathrm{~cm}$ であった。狭窄搪張は $20 \%$ に対して施行 された。また $78 \%$ は外来検査であった。潰瘍性病変は回腸 末端では39\%・遠位回腸では53\%に検出された。活動性病 変とCDAI · CRPとの相関係数は0.11・0.24であった。内視 鏡の通過しない高度狭窄は $22 \%$ 、内瘦は7\%認めた。内視鏡 を基準としたMRECの感度と特異度は、潰瘍性病変では 84\%/90\%、高度狭窄では64\%/92\%、内瘦では94\%/99\%であ った。考察】SBEにより深部小腸を評価することは重要で あった。MRECによる全小腸評価も有用と考えられた。 


\section{S1-09 クローン病の小腸狭窄に対する内視鏡的 \\ バルーン拡張術の有用性と安全性に関する検討}

日本医科大学 消化器内科学

梅田隆満, 田中 周, 西本崇良, 三井啓吾, 岩切勝彦

【目的】バルーン内視鏡 (BAE) によりクローン病 $(\mathrm{CD})$ の小腸病変の病勢評価や内視鏡的バルーン拡張術 (EBD) が可能となったが、CDの小腸狭窄に対するEBDの有用性 と安全性に関する情報は限られているため、それらを明ら かにするために遡及的に検討した。【方法】CD患者に対し てBAEが施行された55症例（199件）を対象とした。EBD は症状の有無にかかわらず、内視鏡が通過不能で、かつ禁 忌のない狭窄病変に対して行われた。評価項目はBAEで $\mathrm{EBD}$ 施行したCD症例の累積非手術率、1症例あたりの平 均EBD回数、1検査当たりのEBD施行病変数、偶発症とし た。【結果】 55例の内訳は性別 $\mathrm{M} / \mathrm{F}: 46 / 9$ 、平均年齢42歳 で、このうち18例に対してEBDを施行した。EBD施行症例 の累積非手術率は1年で93\%、3年で87\%だった。1人あたり の平均 $\mathrm{EBD}$ 回数は平均 3.6 回、1検査あたりの $\mathrm{EBD}$ を施行し た病変数は平均1.9病変だった。BAE199件中2件で偶発症が ありいずれも消化管穿孔だった。【考察】 EBD施行症例の ほとんどで外科手術を回避できCDの維持治療に有用だっ た。消化管穿孔を2例（3.6\%）に認めたが、いずれも初回観 察時であり、EBDに伴う偶発症は皆無で、適応を守れば安 全性の高い治療と考えられた。

S1-11 新型細径シングルバルーン内視鏡の臨床応用 慶應義塾大学医学部 内視鏡センター1)

慶應義塾大学医学部 消化器内科2)

○高林 馨1), 木村佳代子 1), 細江直樹 ${ }^{1)}$, 緒方晴彦1), 金井隆典2)

【目的】今回、新型細径シングルバルーン内視鏡の臨床使用 を行ったのでその有用性について報告する。【方法】当院に て2017年5月から12月までに小腸内視鏡検査を予定された患 者のうち侵襲的処置を必要としない 28 症例を対象として新 型細径シングルバルーン内視鏡による検査を行い、その挿 入性、有効性、安全性などについて検討した。【結果】経口 的に小腸内視鏡検査を施行した患者7名の平均年齢は 42.6 歳、男女比は5:2であり、平均検査時間は24.7分、全例非透 視下、一人法で施行し、全例トライツ勒帯より肛門側への 挿入観察が可能であった。経肛門的に小腸内視鏡検査を施 行した患者 21 名の平均年齢は36.3歳、男女比は $14: 7$ 、一人法 での挿入が 12 例、二人法での挿入が9例であった。平均盲腸 到達時間は 12.3 分で盲腸到達率は $100 \%$ 、平均検査時間は 40.0 分、回盲弁からの平均深部挿入距離は $64.6 \mathrm{~cm}$ であった。 全例外来での検査が可能であり、検査目的達成率は $100 \%$ 、 明らかな偶発症は認められなかった。【考察】侵襲的処置を 必要としない小腸内視鏡検査において新型細径シングルバ ルーン内視鏡は新たな選択肢となりうる可能性が示唆され た。

\section{S1-10 試作細径シングルバルーン内視鏡による クローン病小晹狭窄の治療}

大船中央病院 消化器・IBDセンター

$\bigcirc$ 遠藤 豊, 吉田篤史, 原真太郎, 梅沢翔太郎, 森川吉英 目的 挿入困難例に対する挿入性改善を目的とした細径シン グルバルーン内視鏡（SBE SIF- Y0006,Y0013）が試作され た。細径内視鏡はSIF Q260より、挿入性が優れ、患者の受 容性が高いことを報告してきた。試作スコープは鉗子チャ ンネル径が $2.0 \mathrm{~mm}$ でTTS法による内視鏡的バルーン拡張術 (EBD) はできない。このためover the wire法による治療 をおこなった結果の検討をおこなった。方法 クローン病 でSIF Q260挿入困難例でEBDを試みた13例を対照とした。 先端部外径 $5.4 \mathrm{~mm}$ 、高度伝達蛇管、受動湾曲機構を有する 試作SBEを使用。小腸狭窄部を超えて内視鏡挿入を行い、 ガイドワイヤーを留置。スコープ抜去後バルーンダイレー 夕（CRE Balloon Dilator）を挿入し透視下に拡張術をおこ なった。結果 11例（85\%）でEBD手技に成功した。拡張狭 窄数は2.1(1〜5)であった。不成功 2 例は内視鏡が未到達、バ ルーンダイレータ挿入失敗が1例であった。考察挿入性の 優れたスコープを使用することで通常SBEでの治療ができ ない症例の治療が可能となった。 


\section{シンポジウム 2}

「胃癌内視鏡検診の現況と課題、

そして将来展望」

司会

東京医科大学 消化器内視鏡学分野

河合隆

東京都がん検診センター

入口 陽介 
S2-01 前橋市内視鏡胃がん検診の現沉と課題、そして 将来展望

前橋市医師会1)

群馬県健康づくり財団2)

○萩原廣明 ${ }^{1)}$, 茂木文孝 ${ }^{2)}$, 山下由起子 1), 下田隆也 ${ }^{1)}$, 家崎桂吾1)

【目的】平成16年より直接X線検診との受診者選択制方式で 実施している前橋市内視鏡胃がん検診の現状と課題から、

今後の内視鏡胃がん検診を考える。【現状と課題】内視鏡検 診導入で、受診者数はH16の 20,208 人 (X線検診 16,874 、内 視鏡3,334）からH27には36,083人（7,538、28,545）に増加し た。年代別受診者の増加率は40歳代が最も高かった。胃が ん発見率は直接X線が平均 $0.18 \%$ 、内視鏡が $0.49 \%$ だった。 内視鏡検診の年代別胃がん発見率は、40歳代が $0.10 \% 、 50$ 歳代が $0.17 \%$ 、60歳代が $0.40 \% 、 70$ 歳代が $0.61 \%$ 、80歳以上 が0.95\%だった。H 18から H 25年で要精検率は、X線が $8.3 \%$ から $6.4 \%$ 、内視鏡が $12.0 \%$ から $6.9 \%$ へと低下し、一方、 陽性反応的中度は、X線が $2.6 \%$ から $2.8 \%$ 、内視鏡が $5.2 \%$ か ら6.2\%へと上昇していた。H18からH27年度の逐年受診発 見胃がん279例と $2 \cdot 3$ 年前受診発見胃がん108例の発見時ス テージの比較では、ステージ1発見割合はそれぞれ $89.2 \%$ 、 86.1\%で差はなかった。【今後の展望】逐年検診としていく には更なる精度管理の徹底が必要であり、対象年齢の引き 上げには40歳代受診者にも胃がんが発見されていることを 考慮し節目検診の導入も検討すべきである。

S2-03 太田市胃がん内視鏡検診の現状と取り組み 太田市医師会 ○江原浩司, 関口利和, 中野正美

太田市では検診受診者の減少により1999年から胃個別検診 を開始した。受診者は1999年5,508人受診率 $11.4 \%$ から 2016 年 17,304 人受診率 $23.9 \%$ にまで増加し、個別検診の受診が 94.5\%を占めた。検診医療機関は手上げ方式で、2016年は44 施設（7病院、37診療所）で実施した。2次読影委員会で全 例ダブルチェックを行い、2010年からは画像のファイリン グも行っている。精度管理委員会を年度末ごとに行い、成 績を分析し対策をたてている。症例検討会を年2回開催し、 検診精度と読影能力の向上に努めている。2016年の発見胃

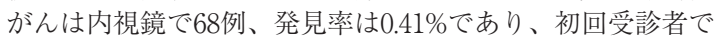
26例（早期10、進行16）、逐年受診者で42例（早期39、進行3） であった。2008年から 2013 年ではABC分類も行い、各群の 発見がん数、発見率はA群62例、0.19\%、B群102例、0.51\%、 C群187例、1.03\%、D群46例、1.17\%であった。2013年から 医師会補助で特定健診受診者にH.pylori 抗体を測定し、胃 がん検診に勧誘するピロリ検診を開始し、2015年から2次読 影時にH.pylori 感染胃炎の評価も行うようにした。今後 H.pylori 抗体とH.pylori 感染胃炎の評価を合わせて行いリ スクに応じた検診間隔を検討している。
S2-02 川崎市医師会に掞ける川崎市胃がん内視鏡検診 への取り組みについて

総合川崎臨港病院11

聖マリアンナ医科大学 消化器・肝臟内科2)

川崎市医師会 ${ }^{31}$

川崎市胃がん・大腸がん検診連絡調整会議委員 ${ }^{4)}$

○渡邊嘉行1, 2, 3, 4), 安田 宏2, 4)

【目的】2012年（平成24年）6月に閣議決定された「がん対 策推進基本計画」をもとに川崎市では川崎市医師会との連 携のもと2012年12月3日から川崎市胃がんX線検診に加えて 胃がん内視鏡検診が導入され 5 年が経過した。今回推移を はじめ複数因子に関して検討考察を行った。【方法】川崎市 胃がん大腸癌検診連絡調整会議に扔ける検診事業業績報告 情報抄よび川崎市医師会による運営状況をもとに情報整理 した。【結果】当初10\%以下であった胃がんX線検診受診率 は、2014年に胃がんX線検診と胃がん内視鏡検診を合わせ て10.6\%となり、2017年には胃がん検診対象者数 369,875 人 に対し、受診者数が 42,548 人 (受診率 $11.5 \%$ ) となった。し かしながら十分な受診率とはいえず、また70歳以下の受診 者数は昨年度比減少（20,063人）にあり、また検診として 重要な精度管理、要生検率等の問題が存在した。【考察】5 年間の推移、諸問題に併せて当初から行われてきた胃がん 内視鏡検診対象者（40歳以上、毎年）に関しても「指針」 にもとづき移行作業を川崎市とすすめており、内視鏡検診 実施に係わる諸費用の面も含めて詳細報告する。

S2-04 胃癌内視鏡検診の導入及び今後の展望

平和台クリニック

○葉井基泰

練馬区では H30年4月より胃癌内視鏡検診の開始予定であ り、それに先立ち50歳以上の胃部 X線検診受診者に対し胃 癌内視鏡検診に関するアンケート調査を行った。内視鏡に よる胃癌検診希望者は67\% ( n=1074) と X線検診希望者よ り多く、その選択理由は84\%が精密な検査が出来ると思っ たからであった。練馬区の胃癌内視鏡健診は隔年で受診可 能で、今年度は練馬区医師会健診センターのみでの施行と なり対象者は50歳の区民約1000人の予定である。 H P 除菌 治療中、抗血栓薬服用者、消化器疾患治療中抢よび経過観 察例は対象外とした。前処置としての鎮痓剤・鎮静剤は用 いず、経口胃内視鏡検查にて施行し、生検は $10 \%$ を目安に 癌が強く疑われるものとした。内視鏡洗浄は機能水を使用 した全自動内視鏡洗浄装置を用いる。二次読影は練馬区医 師会員で日本消化器内視鏡学会専門医を中心に構成された 読影委員会メンバーで行い、C D-Rを媒体とした画像デー 夕と生検結果により判定を行う。H31年4月からは区内の各 医療機関でも開始するため、受診者ファーストの質の高い 内視鏡検診として、区民の期待に応えられるよう今後の展 開や問題点などを含め検討を行う。 
S2-05 横須賀市の胃がんリスク層別化検查、開始後 5 年間の総括

マールクリニック横須賀 1 -

中央内科クリニック2)

○水野靖大 ${ }^{1)}$, 松岡幹雄 ${ }^{2)}$

【目的】平成24年度に、横須賀市は胃がんに関して行う唯一 の市民検診として胃がんリスク層別化検査を選択した。制 度上リピーターの混在がそれまでにない、平成28年度終了 時点で総括を行なった。【方法】各年度のデータは年度終了 後初めての12月1日の時点で締め切った。平成28年度からは 血清ヘリコバクターピロリIgG抗体検査（以降HP検査と記 載）のカットオフ值を $10.0 \mathrm{U} / \mathrm{mL}$ から $3.0 \mathrm{U} / \mathrm{mL}$ に変更し、陰 性高值群は上部消化管内視鏡検査による精密検査後に再評 価した。【結果】 5 年間で 48,950 人、対象の $35.1 \%$ \%受検し た。発見胃がん数は242件で76.86\%は早期がんであった。胃 がん発見率は $0.49 \%$ あるあ。再評価対象のB群は289件あり、 $\mathrm{HP}$ 検査 $10.0 \mathrm{U} / \mathrm{mL}$ 未満の $10.97 \%$ に当たる。再評価では 39.52\%が陽性であった。また、ピロリ菌感染の割合は80代 以上でも6割程度であった。【考察】横須賀市では、この 5 年間で対象者の約 $1 / 3$ が市民検診として胃がんリスク層別化 検査を受検した。除菌後経過観察の報告に課題は残るもの の、早期がんも含めて多くの胃がんが発見され、検診とし て良好な結果であった。

\section{S2-07 内視鏡検診における観察撮影法と拾いあげ所見} の検討

東京都がん検診センター 消化器内科

○依光展和, 入口陽介, 小田丈二

目的：対策型がん検診において十分な死亡率減少効果を発 揮するためには, 精度管理と受診率向上が不可欠であり, 画像検査で行う検診方法では画像精度（胃全体観察）と読 影精度（拾い上げ・生検）が精度管理の上で重要である。 精度の高く効率的な内視鏡検診を確立することを目的に， 観察撮影法と経年発見がん症例について検討した。

方法：当施設の胃観察・撮影法は, 静止画と動画を用いた 観察不良部位の分析結果と経年発見胃癌の検討から, 胃部 37 枚撮影法で統一している (平均 6 分間)。精度管理の指標 となるプロセス評価だけでなく，経年発見胃癌の画像を用 いて分析した。対象は，2008年4月から2016年3月までの8年 間に発見された経年発見胃癌248例。方法は(1)前回検査と発 見時までの期間と深達度, 肉眼型, 部位, (2)前回と発見時 内視鏡像を比較し病変部位が適切に撮影されているか, (3) 前回内視鏡の異常所見の拾い上げ診断能について分析した 成績：観察不良部位の分析では，胃形にもよるが(1)胃体中 部〜胃角後壁, (2)噴門部, (3)角裏の順. 経年発見癌の分析 から早期癌率, 粘膜内癌率は, 1 年 6 か月以内 (178例) は, $98.3 \%, 88.2 \%$. 1 年 7 か月〜 2年 6 か月以内 (43例) は, $90.7 \%, 76.7 \% 。 2$ 年7か月〜3年6か月以内 (27例) は, $68.8 \%, 37.5 \%$ であった。経年発見胃癌のうち，2 年以内の 進行癌は, U領域：6, L 領域：1であり, U領域と小弯に 多い傾向を認めた。前回内視鏡像の分析から，病変部は全 例撮影されており，異常所見を認めたものは221例中210例 (95\%), 発赤, 退色, びらんで, とくにU領域では明らか な胃癌の形態を呈していなかった。

考察：対策型内視鏡検診における統一した観察撮影法は, 効率的なダブルチェックや拾い上げ能の向上に有用であり, 精度向上において重要である。

\section{S2-06 千葉県内3市共通の対策型内視鏡検診開始前画質 テストの現況}

公益財団法人ちば県民保健予防財団 総合健診センター 消化器科 ○山口和也, 中川由紀, 稲田麻里

【目的】千葉県内3市共通の対策型内視鏡検診開始前画質テ ストの現況を報告する。

【対象と方法】千葉県のまず2市において対策型内視鏡検診 について医師会で検討を重ね、医師会内部ではなく当セン ター内に読影委員会を立ち上げ、第三者的な立場で、画質 テストおよびダブルチェックを行うこととなった。全画像 をCD-R、DVD-Rで判定用紙とともに送付いただいた。画 質テストは当センターの専門医3名が評価した。事前の参加 医師毎に内視鏡画質を向上させる取り組みを紹介する。

【結果】検診開始前に各医師会で参加予定者全員参加の説明 講習会を開催し、良い内視鏡画像記録法を説明した。医師 毎に内視鏡画像を提出いただき評価し、改善の余地がある 場合には改善点を指摘し、改善後に再度提出評価する事を 繰り返した。先行開始2市で再提出を必要としたのは139名 中 $28.1 \%$ の医師であった。画質改善後に検診に参加いただい た。平成30年度から加わった市での説明会で先行 2 市の結果 を示し、重要ポイントを強調した。抄録執筆時で画質評価 中の1市では再提出が必要な医師は25名中 $4 \%$ に抑えること ができた。

【結語】講習会でポイントを強調することで内視鏡画像の質 の向上が可能である。

S2-08 H.pylori 除菌後胃癌における細径経鼻内視鏡の 有用性に関する検討

東京医科大学 消化器内視鏡学分野 1

東京医科大学 消化器内科学分野 2 .

○杉本暁彦1), 河合 隆1), 植松淳一1), 福澤誠克 ${ }^{21}$, 系井隆夫2)

背景 : 2013年2月の胃炎におけるH.pylori 除菌適用追加によ り年間 150 万人以上の患者が除菌されており、内視鏡検診の 対象者においても除菌後の患者が多く含まれる事が予想さ れる。今回、除菌後胃癌に抄ける細径経鼻内視鏡粘膜構造 診断の有用性を検討した。

対象・方法：対象は2012年7月から2017年11月の間に経鼻内 視鏡を行った除菌後陷凹性胃癌11例である。平均年齢68才 である。細径経鼻内視鏡としてGIF-XP290Nを用いた。病 変を認めた場合、白色光 (WLI)、インジゴカルミン色素観 察 (DYE) さらにNBI超近接観察(NBC)にて粘膜構造を観 察した。白色光及び色素観察は従来の方法に従い、NBI併 用超近接観察では、病変に約 $3 \mathrm{~mm}$ 近接し陥凹部の粘膜模様 を観察した。病変のdemarcation lineの有無と併せて、粘膜 模様パターンを”無構造”及び明らかな不揃い・不整”を 異常粘膜、”ほほ正常・均一”の3つに分類した。病変部は 全例組織を採取し病理学的に最終診断した。さらに一部の 症例では拡大観察を追加した。

結果：部位はU領域：1 例、 $\mathrm{M}$ 領域：2 例、 $\mathrm{L}$ 領域：8例で あった。陷凹型の診断はWLI：18.2\%、DYE：18.2\%、 NBI : 72.7\%とNBIにて明らかに高かった。後日ESDにて胃 癌部表層上皮の異型度が低い症例においても、経鼻では粘 膜構造の異常を観察可能であつた。

結語：解像度が低く、観察深度が広い経鼻内視鏡のNBI近 接観察では、除菌による影響が少ないと思われた。細径経 鼻内視鏡NBI超近接観察による粘膜模様観察は、H.pylori 除菌後胃がんスクリーニングにおいても、有用な診断ツー ルであると思われる。 